\title{
Gjesteredaktørenes innledning
}

Thorgeir Kolshus thoko@oslomet.no

Per Inge Båtnes peri@oslomet.no

Seksjon for mangfoldsstudier Institutt for internasjonale studier og tolkeutdanning OsloMet - Storbyuniversitetet 
I 2017 fylte Seksjon for flerkulturelle studier ved Høgskolen i Oslo og Akershus tyve år. Anledningen ble behørig markert med gjesteforelesninger, paneldebatt og satireshow. I tillegg ble det avholdt et internt fagseminar der seksjonens ansatte la frem arbeider som skulle tematisere erfaringer fra disse tyve årene, med henblikk på å utgi et spesialnummer av FLEKS. Vi ble enige om ikke å gjøre dette til et festtalenummer, men snarere benytte anledningen til å bedrive refleksiv fagkritikk.

Halvannet år senere er dette nummeret blitt virkelighet. I mellomtiden har HiOA blitt til OsloMet, mens jubilanten er omdøpt til Seksjon for mangfoldsstudier og har økt i antall ansatte fra fem til tretten. Den fagkritiske intensjonen, gjenspeilet i tittelen på dette nummeret, har imidlertid overlevd disse endringene. De tre artiklene og to essayene vi har gleden av å dele med leserne er svært ulike, preget som de er av Seksjon for mangfoldsstudiers flerfaglige forskningsprofil. Samtidig berører alle bidragene både den umiddelbare fascinasjonen og den mer tvisynte ettertanken som stadig kjennetegner seksjonens tematiske virkeområde, og som vi møter $\mathrm{i}$ våre respektive forskningsfelt og $\mathrm{i}$ de mangslungne erfaringene hos våre studenter gjennom disse tyve årene, som stort sett samtlige har vært profesjonsutøvere i ulike førstelinjetjenester.

Seksjonens og studienes navneendringer kan også leses kunnskapsarkeologisk. Skiftet fra det opprinnelige 'flerkulturell forståelse' til 'flerkulturell fagkompetanse' var et langt mer radikalt epistemologisk grep enn det kunne synes ved første øyekast. Det flyttet nemlig oppmerksomheten vekk fra ubestandig og generaliserende kunnskapselementer, av typen «Hvordan tenker en tyrker», til varige og overførbare refleksive ferdigheter, først og fremst knyttet til selvinnsikt gjennom forståelse av egne kulturelle forutsetninger. Seksjonen ønsket ikke lenger å være en del av forståelsesindustrien, der «De andre» fremstilles som besatt av kultur, mens «Vi» i beste fall besitter den, og der en altfor løssluppen bruk av begreper som 'flerkulturell' og 'minoritetsspråklig' skapte forventninger om forskjeller som lett ble selvbekreftende på samhandlingsplan, der folks liv faktisk leves.

For oss har det også vært viktig å påpeke at det ofte ikke er samsvar mellom intensjoner og konsekvenser. På en av de største utdanningene ved HiOA/OsloMet ble for ikke lenge siden alle studenter med ikke-europeiskklingende etternavn invitert til en egen samling. De møtte opp, lettere i villrede over formålet, og ble ønsket velkommen med følgende åpningssetning: «Dere er juvelene våre!» I salen satt noen som var kommet til Norge som flyktninger for bare et par år siden, mens andre hadde besteforeldre som hadde flyttet hit seksti år tidligere: Det eneste de hadde til felles var at hudfargen deres hadde en annen lød enn de tre lærernes. Hensikten var at studentene skulle føle seg hjemme på studiet. Utfallet for de fleste ble fremmedgjøring, ettersom lærernes tiltak, gjennomsyret av velvilje, minnet disse studentene på at lærerne tenkte på dem som noe annet enn bare studenter.

Veien er kort fra velviljens klønerier til de senkede forventingers rasisme, og derfra videre til en del av de reelle dilemmaer som oppstår når sentrale verdibaserte prinsipper kommer i konflikt. Ved en skole på Oslos indre østkant er det for eksempel en ikke-skreven regel om at ingen kan dra på overnattingstur lengre vekk enn en time med buss, slik at de jentene som ikke får lov til å sove hjemmefra, kan bli hentet på kvelden. Bakgrunnen for praksisen er at klasseturer skal være fellesskapsfremmende, og at de derfor må utformes slik at alle kan være med. Samtidig setter man da et uformelt godkjentstempel på patriarkalsk sosial kontroll, stikk i strid med femti års kvinnekamp og brede politiske likestillingsmål. Det kan altså leses som et svik mot disse jentene, som med skolens velvillige hjelp fratas opplevelsesmuligheter ingen norskættet lærer ville drømt om å nekte sine egne døtre.

En rekke nyere publikasjoner fra forskere som arbeider med migrasjonsrelaterte spørsmål, viser hvordan slike dilemmaer i de første par tiårene av norsk innvandringsforskning sjelden ble åpent diskutert - og at de som gjorde det, lett fikk trukket sin moral i tvil (se for eksempel Midtbøen, 2017; Wikan, 2017). Heldigvis later situasjonen nå til å være en annen. Det er et kvalitetstegn ved den norske debatten at samfunnsvitere har anledning til å lufte også sin uro over utviklingstrekk som berører dem både som nysgjerrige forskere og engasjerte borgere 
(Andersson, 2018; Midtbøen og Pedersen, 2019). Skepsis mot ukritisk import av teorier av amerikansk opphav knyttet til identitetshåndtering og forestilling om rase, som ofte bygger på særegne kulturelle og historiske forutsetninger uten paralleller på den andre siden av Atlanterhavet, er likeledes et kvalitetstegn (Friberg \& Midtbøen, 2017: 10; Kolshus, 2018).

Seksjon for mangfoldsstudier ved OsloMet ønsker å bidra til at forskning og fagdebatt de neste tyve årene fortsetter å være styrt av genuin nysgjerrighet og vitebegjær, med generelle innsikter som skal være forankret i solide empiriske studier. Reelle dilemmaer, og endog regelrette bekymringer, skal påpekes snarere enn forbigås i stillhet. Det vil også innebære den lenge etterlyste 'dekonstruksjonen av majoriteten', gjennom både å utfordre forestillingen om norsk kulturell homogenitet og å peke på at i enkelte lokalmiljøer vil enkelte majoritetsnordmenns liv bære mange av kjennetegnene ved en minoritetskulturell tilværelse. På det viset vil vi bidra til en enda mer opplyst offentlig samtale. Dette nummeret kan leses som en spe begynnelse. God lesning!

Vi vil rette en stor takk til de anonyme fagfellene, som har bidratt til å heve kvaliteten på de tre fagartiklene. Videre vil vi gi en stor takk til Susanna Calvert for en fremragende jobb med selve redigeringen av dette nummeret. Vi er også veldig takknemlige for publiseringsstøtte fra OsloMet. 


\section{Litteratur}

Andersson, M. (2018). Kampen om vitenskapeligheten: Forskningskommunikasjon i et politisk betent felt. Oslo: Universitetsforlaget. https://www.idunn.no/kampen-omvitenskapeligheten

Friberg, J.H. og A. Midtbøen (2017). Innvandrernes etterkommere: Teoretiske og komparative perspektiver. Norsk Sosiologisk Tidsskrift 1 (1): 5-14.

https://www.idunn.no/norsk_sosiologisk tidsskrift/2017/01/innvandrernes etterkomm ere teoretiskeog komparative persp

Kolshus, T. (2018). Fra grobunn til stengrunn. Kulturrelativismens skjebne i norsk offentlighet. Norsk Antropologisk Tidsskrift 29 (1-2): 42-57. https://doi.org/10.18261/issn.1504-2898-2018-01-02-04

Midtbøen, A. (2017). Innvandringshistorie som faghistorie: Kontroverser i norsk migrasjonsforskning. Nytt Norsk Tidsskrift 34: 130-149. https://doi.org/10.18261/issn.1504-3053-2017-02-03

Midtbøen, A. og A.W. Pedersen (red.) (2019). Boksymposium: Ubehaget i migrasjonsforskningen. Tidsskrift for Samfunnsforskning 60 (1): 74-116. https://doi.org/10.18261/issn.1504-291X-2019-01-04

Wikan, U. (2017). Perils and Prospects of Going Public: Between Academia and Real Life. I D. Fassin (red.) If truth be told (s. 228-260). Durham, NC: Duke University Press. https://doi.org/10.1215/9780822372875-011 